\title{
Corrosion Inhibition of Aluminum Alloy 2024-T3 by Aqueous Vanadium Species
}

\author{
K. D. Ralston, ${ }^{\mathrm{a}, *, \mathrm{z}}$ S. Chrisanti, ${ }^{\mathrm{a}, *}$ T. L. Young, ${ }^{\mathrm{b}}$ and R. G. Buchheit ${ }^{\mathrm{a}, * *}$ \\ ${ }^{a}$ Fontana Corrosion Center, Department of Materials Science and Engineering, The Ohio State University, \\ Columbus, Ohio 43210, USA \\ ${ }^{b}$ Department of Chemistry, The Ohio State University, Columbus, Ohio 43210, USA
}

Nuclear magnetic resonance (NMR) measurements were made on aqueous vanadate solutions to characterize speciation as a function of $\mathrm{pH}$ and vanadate concentration. Additionally, potentiodynamic polarization measurements were carried out on $\mathrm{Al}$ alloy 2024-T3 in $50 \mathrm{mM} \mathrm{NaCl}$ solutions in which $\mathrm{pH}$ and vanadate concentration were systematically varied. Results showed that inhibition by vanadates occurred mainly in alkaline solutions where tetrahedrally coordinated vanadates, metavanadate and pyrovanadate, were abundant. Inhibition was not observed in solutions where octahedrally coordinated decavanadates predominated. Anodic inhibition, in the form of increased pitting potential, was observed in both aerated and deaerated solutions. In contrast, cathodic inhibition was observed only in aerated solutions acting primarily through the suppression of oxygen reduction. Energydispersive spectroscopy, used to collect chemical maps from aluminum coupons exposed to vanadate solutions, showed the suppression of $\mathrm{Al}_{2} \mathrm{CuMg}$ particle dissolution compared to vanadate-free solutions. NMR measurements were also used to track changes in vanadate speciation with time, $\mathrm{pH}$ adjustment, and with exposure to metallic aluminum surfaces. NMR showed noninhibiting octahedrally coordinated decavanadates rapidly decompose into inhibiting tetrahedrally coordinated metavanadates and pyrovanadates after alkaline $\mathrm{pH}$ adjustment. While decomposition begins immediately upon $\mathrm{pH}$ adjustment, equilibrium may not be reached even after significant time periods.

(C) 2008 The Electrochemical Society. [DOI: 10.1149/1.2907772] All rights reserved.

Manuscript submitted January 29, 2008; revised manuscript received March 17, 2008. Available electronically May $19,2008$.

Vanadates have shown promise as alternatives to chromates as inhibitors to protect aluminum alloys such as $2024-\mathrm{T} 3 .{ }^{1-7}$ In particular, vanadates in $\mathrm{NaCl}$ solutions have been shown, under specific conditions, to be modest anodic inhibitors and potent cathodic inhibitors for $2024 .^{3-8}$ Furthermore, there are ways to functionalize soluble vanadates through the formation of films and conversion coatings, and by incorporation into organic coatings. ${ }^{7-12}$ Additionally, a number of vanadate surface treatments and pigmented organic coatings applied to zinc and aluminum substrates have been observed to "self-heal" in a fashion resembling that shown by chromate-based coatings. $7,11,12$

Whether soluble vanadates provide inhibition of Al 2024-T3 is strongly dependent on the solution $\mathrm{pH}$. Guan and Buchheit et al. reported an approximately $100 \mathrm{mV}$ increase in pitting potential for a $0.124 \mathrm{M} \mathrm{NaCl}$ solution at $\mathrm{pH} 6$ with $0.1 \mathrm{M} \mathrm{NaVO}_{3}$ with little effect on the rate of oxygen reduction. ${ }^{7,8}$ Cook observed a 2 order of magnitude decrease in corrosion current from polarization measurements in $0.6 \mathrm{M} \mathrm{NaCl}$ solution at $\mathrm{pH} 7$ with $3.4 \mathrm{mM} \mathrm{NaVO}_{3}$ on $\mathrm{Al}$ 2024-T3, similar to the decrease observed for sodium chromate additions. ${ }^{6}$ Furthermore, electrochemical impedance spectroscopy measurements on $\mathrm{Al} 2024-\mathrm{T} 3$ samples exposed to $0.6 \mathrm{M} \mathrm{NaCl}$ solutions with $3.4 \mathrm{mM} \mathrm{NaVO}_{3}$ carried out over 10 days showed aqueous $\mathrm{NaVO}_{3}$ was poorly protective at $\mathrm{pH} 3$ but was inhibiting at $\mathrm{pH}$ 7 and $10 .{ }^{6}$ Iannuzzi et al. observed significant decreases in cathodic kinetics in $0.5 \mathrm{M} \mathrm{NaCl}$ solutions containing $10 \mathrm{mM} \mathrm{NaVO}$ at $\mathrm{pH}$ values ranging from 7.8 to $9.3^{3}{ }^{3}$

$\mathrm{V}^{5+}$ has a complex aqueous chemistry which depends on $\mathrm{pH}$ and concentration, as seen in the equilibrium speciation diagram in Fig. $1 .^{13,14}$ Although there is some disagreement in the literature as to the exact $\mathrm{pH}$ at which particular species dominate, the following is a summary with nomenclature, solution color, and $\mathrm{pH}$ range of the various species under consideration. Orthovanadates $\left(\mathrm{VO}_{4}^{3-}\right)$ are colorless and dominate at a solution $\mathrm{pH}$ greater than $13 .{ }^{13,15}$ As highly basic solutions are acidified to $\mathrm{pH}$ values between 9 and 12, orthovanadate tetrahedral units can combine to form pyrovanadates $\left[\mathrm{V}_{2} \mathrm{O}_{7}^{4-}, \mathrm{HV}_{2} \mathrm{O}_{7}^{3-}\right.$, and $\left.\mathrm{VO}_{3}(\mathrm{OH})^{2-}\right]$ which are also colorless. ${ }^{13,15}$ Continued acidification to $\mathrm{pH}$ values between 6 and 9 leads to the formation of colorless or yellow metavanadates $\left[\mathrm{V}_{3} \mathrm{O}_{9}^{3-}, \mathrm{V}_{4} \mathrm{O}_{12}^{4-}\right.$,

\footnotetext{
* Electrochemical Society Student Member.

z E-mail: ralston@matsceng.ohio-state.edu
}

$\mathrm{V}_{5} \mathrm{O}_{15}^{5-}, \mathrm{VO}(\mathrm{OH})_{3}$, and $\left.\mathrm{VO}_{2}(\mathrm{OH})_{2}^{-}\right] \cdot{ }^{13-16}$ Additional acidification to $\mathrm{pH}$ between 2 and 6 causes the coordination of vanadium to change from tetrahedral to octahedral. A combination of ten octahedral units form the decavanadate ion $\left[\mathrm{V}_{10} \mathrm{O}_{28}^{6-}, \quad \mathrm{V}_{10} \mathrm{O}_{27}(\mathrm{OH})^{5-}\right.$, $\left.\mathrm{V}_{10} \mathrm{O}_{26}(\mathrm{OH})_{2}^{4-}\right]$, which leads to orange or red solutions. ${ }^{13-15}$ Pervanadyl $\left(\mathrm{VO}_{2}^{+}\right)$is yellow and dominates at dilute concentrations in strongly acidic solutions. ${ }^{13-15}$ As seen in Fig. 1, small concentrations of vanadate exist exclusively as monovanadate species, while higher vanadate concentrations result in larger species consisting of multiple vanadium atoms. ${ }^{13}$ Although a specific species will be dominant at a certain $\mathrm{pH}$ and concentration combination, a number of other species are present in a solution in smaller but appreciable proportions. ${ }^{13}$ As a result, complex equilibria may mask which species are the cause of inhibition and to what extent. Equilibria be-

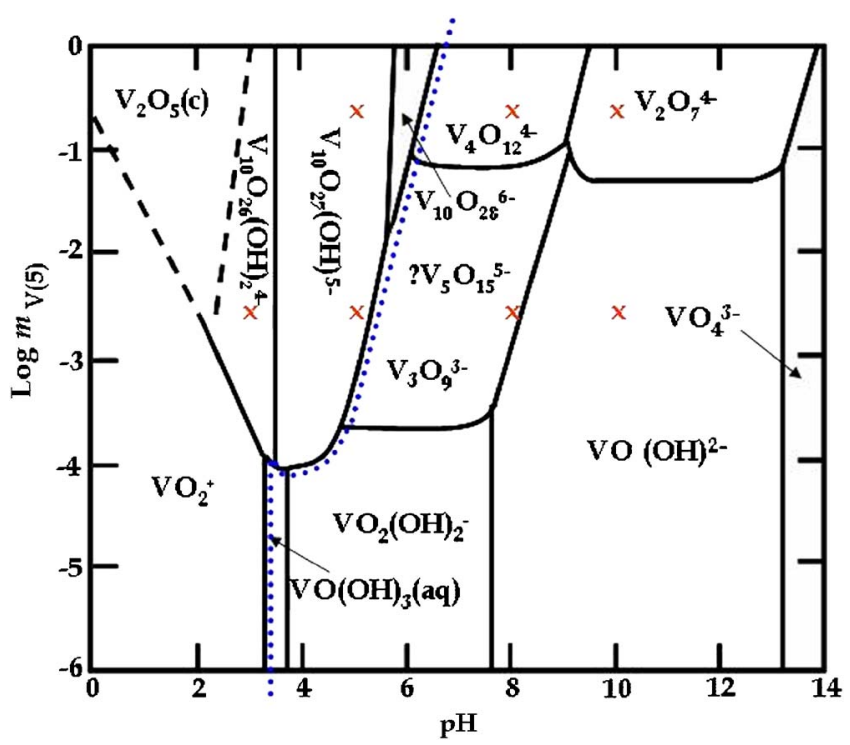

Figure 1. (Color online) Equilibrium predominance diagram for $\mathrm{V}^{\mathrm{V}}-\mathrm{OH}^{-}$ species as a function of concentration and $\mathrm{pH}$ (adapted from Ref. 13 and 14). The dotted line indicates delineation between octahedral coordinated and tetrahedral coordinated vanadate species. Approximate $\mathrm{pH}$ and concentration of test solutions are indicated with an "x." 
tween different vanadate species has generally been reported to occur quickly, except for the equilibrium between metavanadate and decavanadate; when approached from the acidic side, equilibrium is established only after several hours and possibly involves the formation of intermediate species. . $^{-15}$

There is a body of evidence that suggests that vanadates are inhibitors of corrosion, and it seems likely that inhibition depends on speciation; however, this relationship has not been fully characterized. The objective of this work is twofold: $(i)$ to systematically characterize vanadate speciation and inhibition over a range of $\mathrm{pH}$ and vanadate concentrations, and (ii) to further the understanding of inhibition mechanisms and the roles that various vanadate species have in those mechanisms.

\section{Experimental}

Materials and chemicals.-A $2.0 \mathrm{~mm}$ thick Al 2024-T3 sheet was used in all electrochemical and exposure experiments. Aluminum 2024-T3 is a solution heat-treated and cold-worked alloy whose nominal composition is $\mathrm{Al}, 3.8-4.9$ wt \% Cu, $1.2-1.8$ wt \% $\mathrm{Mg}, 0.3-0.9$ wt $\% \mathrm{Mn}, 0.5$ wt $\% \mathrm{Fe}, 0.5$ wt $\% \mathrm{Si}, 0.25$ wt $\% \mathrm{Zr}$, $0.1 \mathrm{wt} \% \mathrm{Cr}$, and $0.1 \mathrm{wt} \% \mathrm{Ti} .{ }^{17}$ Solutions for potentiodynamic polarization and exposure experiments were prepared using reagentgrade $\mathrm{NaCl}, 10 \mathrm{~N} \mathrm{NaOH}$ solution, and $\mathrm{HCl}$ purchased from Fisher Scientific, and $\mathrm{NaVO}_{3}$ (assay $\geq 98 \%$ ) purchased from Fluka Chemika. The $\mathrm{NaVO}_{3}$ used for nuclear magnetic resonance (NMR) measurements was obtained from Alfa Aesar (assay 96\%). $18.2 \mathrm{M} \Omega \mathrm{cm}$ deionized (DI) water was used for preparation of all solutions.

Sample preparation.- Samples for potentiodynamic polarization experiments were prepared by abrading Al 2024-T3 coupons with a Scotch-Brite pad for 15-20 s. The samples were then rinsed with tap water to remove debris followed by a DI water rinse. The coupons were dried using an air hose, and experiments were carried out within minutes of sample preparation. This method allowed for quick and easy sample preparation and reproducible results. For solution exposure experiments, $\mathrm{Al} 2024-\mathrm{T} 3$ sheets were cut into coupons, $2 \times 2 \mathrm{~cm}$, and mounted in epoxy to avoid any possible galvanic coupling associated with conductive Bakelite mounting media. Coupons for the exposure experiments were polished with $\mathrm{SiC}$ paper and finished with $1 \mu \mathrm{m}$ diamond paste. Ethyl alcohol was used for the last $\mathrm{SiC}$ polishing step and subsequent diamond paste polishing to help avoid onset of corrosion prior to experimentation. Samples were washed using an ultrasonic bath and ethyl alcohol prior to experiments to remove any residual polishing media.

NMR.- A Bruker DPX $400 \mathrm{MHz}$ superconducting magnet was used to collect high-resolution ${ }^{51} \mathrm{~V}(105.2 \mathrm{MHz}) \mathrm{NMR}$ spectra. An indirect detection probe was used with a $90^{\circ}$ pulse duration of $10.38 \mu \mathrm{s}$. Spectra were collected using 1024 transients, a spectral window of $73,529 \mathrm{~Hz}$, a $0.051 \mathrm{~s}$ acquisition time, and a $0.20 \mathrm{~s}$ relaxation delay. Each spectrum had the subsequent process parameters applied: $1.00 \mathrm{~Hz}$ line broadening, zero filling $(25 \mathrm{~K}$ points), and baseline correction. A solution consisting of $20 \% \mathrm{v} / \mathrm{v}$ $\mathrm{VOCl}_{3}$ in $\mathrm{C}_{6} \mathrm{D}_{6}\left(\delta^{51} \mathrm{~V}=0 \mathrm{ppm}\right)$ was used as an external standard to reference the ${ }^{51} \mathrm{~V}$ chemical shifts.

Four different NMR experiments were run. In the first experiment, a $100 \mathrm{mM}$ as-dissolved $\mathrm{NaVO}_{3}$ solution, initial $\mathrm{pH}$ 8.76, was acidified to $\mathrm{pH} 4.12$ with $\mathrm{HNO}_{3}$, followed by a $\mathrm{pH}$ adjustment to 7.58 with $\mathrm{NaOH}$ to observe the kinetics of decavanadate decomposition. In the initial solution, once the $\mathrm{NaVO}_{3}$ was dissolved the solution $\mathrm{pH}$ remained stable. NMR spectra of the initial $\mathrm{pH}$-adjusted and readjusted solution were conducted within a few minutes of $\mathrm{pH}$ modification. NMR spectra and $\mathrm{pH}$ measurements were taken with time over a period of $1468 \mathrm{~h}$. A second experiment was conducted to observe the effects of multiple $\mathrm{pH}$ adjustments on a $\mathrm{NaVO}_{3}$ solution. Using a pH $6.08 \mathrm{NaVO}_{3}$ solution produced after $1468 \mathrm{~h}$ of equilibration in the previously mentioned experiment, the $\mathrm{pH}$ was adjusted by one-drop additions of $\mathrm{NaOH}$ at 0,24 , and $51 \mathrm{~h}$. To char- acterize the solution throughout the experiment, NMR spectra were collected and $\mathrm{pH}$ was measured for samples of the initial solution, a solution after $2 \mathrm{NaOH}$ additions collected prior to the third $\mathrm{NaOH}$ addition (spectrum at $52 \mathrm{~h}$ of total time), and a solution after three $\mathrm{NaOH}$ additions (spectrum at $52 \mathrm{~h}$ total time). A third experiment was conducted to observe the effects of $\mathrm{NaVO}_{3}$ solution exposure to aluminum. A $2.0 \mathrm{~mm}$ diameter aluminum wire $(99.999 \%)$ obtained from Alfa Aesar was abraded with 600 grit $\mathrm{SiC}$ paper, cleaned with alcohol, and placed inside an NMR tube in contact with the final aged $\mathrm{pH} 6.08 \mathrm{NaVO}_{3}$ solution produced after $1468 \mathrm{~h}$ of equilibration from the previously mentioned first NMR experiment. Another experiment was run in parallel where an aluminum wire was placed in contact with an equilibrated $\mathrm{pH} 8.10 \mathrm{NaVO}_{3}$ solution that contained primarily tetrahedral vanadate species. The wires were removed and subsequent NMR spectra were collected at $52 \mathrm{~h}$. A final NMR experiment was used to determine what vanadate species resulted from a vanadate hydrotalcite pigment exposed to $\mathrm{NaCl}$ solution. Hydrotalcite pigments are being evaluated for possible use as inhibitor pigments. ${ }^{8,18-20}$ The pigments were synthesized by the coprecipitation of zinc and aluminum chlorides in an orange decavanadate solution. Of the resultant decavanadate-hydrotalcite pigment, 4.0 grams were soaked in $40 \mathrm{~mL}$ of $0.1 \mathrm{M} \mathrm{NaCl}$ for $20 \mathrm{~h}$, at which time a sample of this solution was taken for NMR analysis.

Potentiodynamic polarization.- To characterize the inhibitive nature of vanadate, anodic and cathodic polarization curves were collected for $\mathrm{Al}$ 2024-T3 coupons in aerated and deaerated $50 \mathrm{mM}$ $\mathrm{NaCl}$ solutions with $\mathrm{NaVO}_{3}$ additions resulting in $0.0,0.0032$, and $0.32 \mathrm{M} \mathrm{NaVO}_{3}$ and with $\mathrm{pH}$ adjustments to $3,5,8$, and 10 . This approach created a matrix of test solutions which when considered relative to the equilibrium predominance diagram for vanadate, allowed characterization of the inhibitive effects of a number of different vanadate species. $\mathrm{NaVO}_{3}$ is a buffer, and at $\mathrm{pH} 5$, the $0.32 \mathrm{M}$ $\mathrm{NaVO}_{3}$ solution required enough $\mathrm{HCl}$ to cause the overall $\mathrm{Cl}^{-}$concentration to be nearly $4 \times$ that of other test solutions. For this reason, a $0.32 \mathrm{M} \mathrm{NaVO}_{3}$ solution at $\mathrm{pH} 3$ was not used in the experiments. To differentiate the effects of $\mathrm{NaVO}_{3}$ inhibition from $\mathrm{pH}-$ induced changes, measurements were made in $\mathrm{NaVO}_{3}$-free solutions and the solution $\mathrm{pH}$ was measured before and after every experiment to ensure the solution $\mathrm{pH}$ remained near the intended $\mathrm{pH}$.

Polarization curves were replicated a minimum of four times in aerated solutions and twice in deaerated solutions. All polarization experiments were carried out in a flat cell using a standard threeelectrode setup consisting of saturated calomel reference electrode (SCE), a platinum counter electrode mesh, and an Al 2024-T3 working electrode. Measurements were conducted using Princeton Applied Research potentiostat/galvanostat, models 263A or 273A, in conjunction with Corrware data acquisition software. The exposed sample area of each $\mathrm{Al} 2024-\mathrm{T} 3$ coupon was $1 \mathrm{~cm}^{2}$. All polarization curve measurements were preceded by a 30 min measurement of the open-circuit potential (OCP). Anodic polarization curves were initiated $-30 \mathrm{mV}$ vs the OCP and reversed at $3.93 \times 10^{-4} \mathrm{~A} / \mathrm{cm}^{2}$, finishing at $-30 \mathrm{mV}$ vs OCP. A scan rate of $0.5 \mathrm{mV} / \mathrm{s}$ was used in all experiments. Cathodic polarization curves were initiated $+30 \mathrm{mV}$ vs the OCP and finished at $-2.0 \mathrm{~V}$ vs OCP. Most cathodic polarization curves were stopped before $-2.0 \mathrm{~V}$ vs OCP was reached, but well after hydrogen evolution had begun.

Exposure experiments.- Al 2024-T3 coupons were exposed to different vanadate solutions to explore variations in corrosion damage accumulation as a function of $\mathrm{pH}$ and $\mathrm{NaVO}_{3}$ concentration. Exposure experiments were conducted in actively aerated $200 \mathrm{~mL}$ solutions of the same $\mathrm{pH}$-concentration combinations used in the polarization experiments. For comparison, a parallel set of samples was exposed to chloride solutions that did not contain $\mathrm{NaVO}_{3}$. Exposure experiment solutions were held for $1 \mathrm{~h}$ prior to use to allow time for solution equilibration. All samples were placed face up in beakers containing test solutions for $2.5 \mathrm{~h}$ as air was actively bubbled. The samples were carefully removed, gently rinsed with 


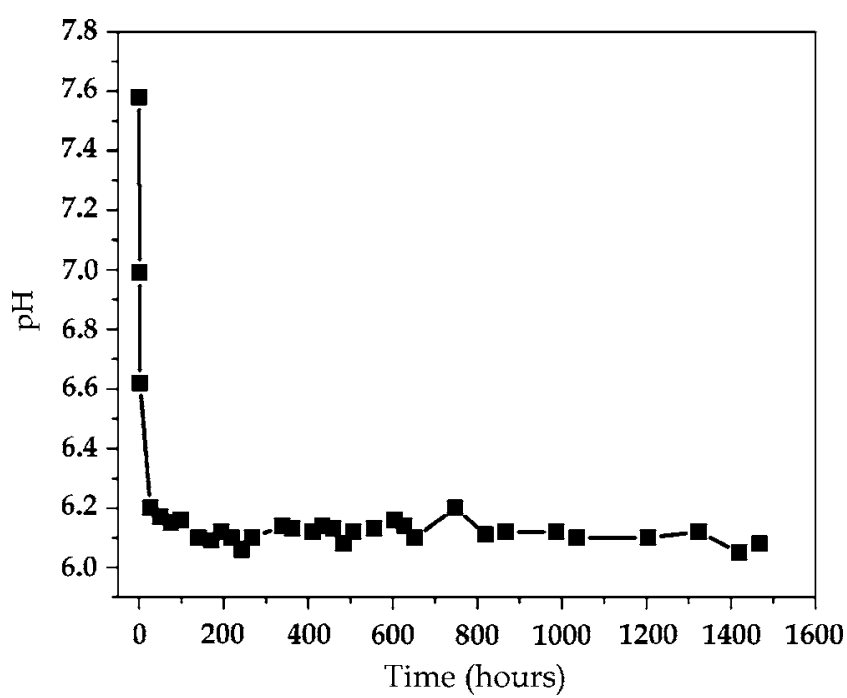

Figure 2. Change in $\mathrm{pH}$ as a function of time of a $\mathrm{pH} 8.76100 \mathrm{mM} \mathrm{NaVO}_{3}$ solution initially acidified to $\mathrm{pH} 4.12$ with $\mathrm{HNO}_{3}$ and then adjusted to $\mathrm{pH}$ 7.58 with $\mathrm{NaOH}$.

ethyl alcohol, and allowed to air dry. Samples were then examined using a Quanta 200 scanning electron microscope equipped with energy-dispersive spectrometry (EDS) capabilities.

\section{Results}

Changes in vanadate speciation with $\mathrm{pH}$ adjustment, time, and exposure to aluminum.- The decomposition of decavanadate to metavanadate in an initially acidic vanadate solution whose $\mathrm{pH}$ was adjusted into the basic regime was characterized by NMR. The goal of these experiments was to observe how quickly octahedrally coordinated decavanadate formed tetrahedrally coordinated species after an increase in solution $\mathrm{pH}$. Figure 2 shows changes in $\mathrm{pH}$ of a $100 \mathrm{mM} \mathrm{NaVO}_{3}$ solution initially $\mathrm{pH} 8.76$ then acidified to $\mathrm{pH} 4.12$ with $\mathrm{HNO}_{3}$, followed by $\mathrm{pH}$ adjustment to $\mathrm{pH} 7.58$ with $\mathrm{NaOH}$. These measurements were made to record $\mathrm{pH}$ changes in solutions on which NMR measurements were made. The initial $\mathrm{NaVO}_{3}$ solution was clear and turned a brilliant deep orange color upon acidification. After $\mathrm{pH}$ adjustment from $\mathrm{pH} 4.12-7.58$ the solution remained a brilliant orange color with no observable color change. The $\mathrm{pH}$ was observed to drop to 6.2 within $27 \mathrm{~h}$ and remained between 6.05 and 6.2 over the next $1441 \mathrm{~h}$. Figure 3 is a collection of NMR spectra that shows changes in the vanadate speciation as a function of time. Identification of vanadate species from NMR measurements was made by comparison to literature. ${ }^{16,21-23}$ As seen in Fig. 3, the initial as-dissolved vanadate solution contained monovanadates, $\mathrm{VO}(\mathrm{OH})_{3}, \mathrm{VO}_{2}(\mathrm{OH})_{2}^{-}$; and $\mathrm{VO}_{3}(\mathrm{OH})^{2-}\left(\mathrm{V}_{1}\right)$; divanadates $\mathrm{V}_{2} \mathrm{O}_{7}^{4-}$ and $\mathrm{HV}_{2} \mathrm{O}_{7}^{3-}\left(\mathrm{V}_{2}\right)$; cyclic tetravanadates, $\mathrm{V}_{4} \mathrm{O}_{12}^{4-}\left(\mathrm{V}_{4}\right)$; and cyclic pentavanadates, $\mathrm{V}_{5} \mathrm{O}_{15}^{5-}\left(\mathrm{V}_{5}\right)$ species. ${ }^{3,13-15,21}$ Cyclic species are typically combinations of tetrahedrally coordinated monovanadates. After the $\mathrm{pH}$ was adjusted to 4.12 , tetrahedrally coordinated metavanadate and pyrovanadate fully transform to decavanadate within the detection limits of the experiment, $\mathrm{V}_{10} \mathrm{O}_{28}^{6-}$, $\mathrm{V}_{10} \mathrm{O}_{27}(\mathrm{OH})^{5-}, \mathrm{V}_{10} \mathrm{O}_{26}(\mathrm{OH})_{2}^{4-}\left(\mathrm{V}_{10}\right){ }^{13,14,16}$ The solution $\mathrm{pH}$ was then readjusted to 7.58 and formation of $\mathrm{V}_{1}, \mathrm{~V}_{2}$, and $\mathrm{V}_{4}$ were observed within minutes. The relative amounts of metavanadate and pyrovanadate in comparison to decavanadate continued to increase with time, despite a decrease in solution $\mathrm{pH}$. Although the initial formation of metavanadate and pyrovanadate from decavanadate is observed to occur rapidly, the solution continued to equilibrate for hundreds of hours. These experiments show that relatively modest increases in $\mathrm{pH}$ trigger rapid formation of tetrahedrally coordinated metavanadate and pyrovanadate species, which persist even in mildly acidic solutions.

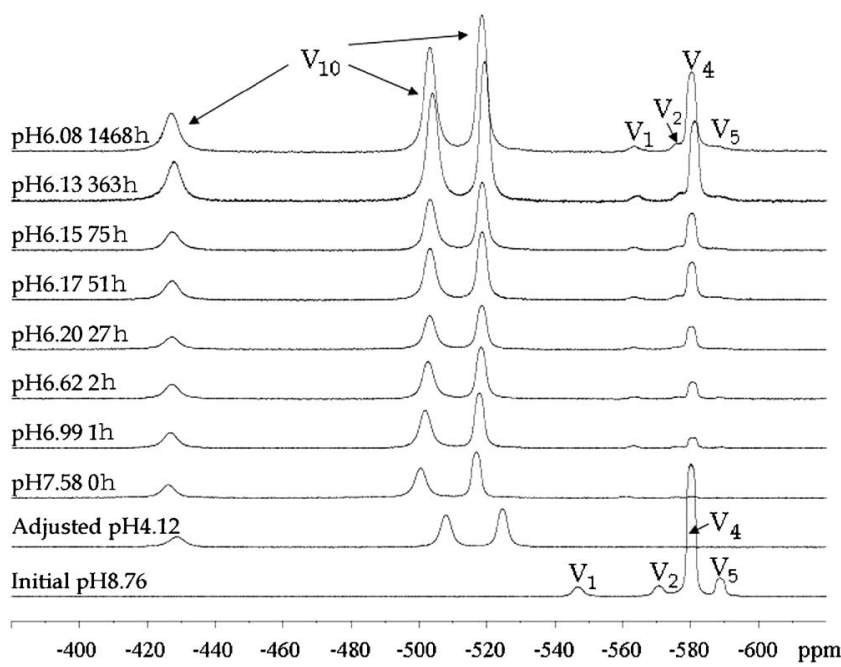

Figure 3. NMR spectrum as a function of time of a $100 \mathrm{mM} \mathrm{NaVO}_{3}$ solution initially acidified to $\mathrm{pH} 4.12$ with $\mathrm{HNO}_{3}$ and then adjusted to $\mathrm{pH} 7.58$ with $\mathrm{NaOH}$.

Figure 4 shows the effect of serial $\mathrm{NaOH}$ additions upon speciation in $100 \mathrm{mM} \mathrm{NaVO}$ solution. The aim of this experiment was to observe vanadate speciation in the presence of a "continuous" source of alkalinity, as might occur in the vicinity of a cathode in a localized corrosion cell. The initial solution was orange with a $\mathrm{pH}$ of 6.08 and contained decavanadate, metavanadate, and pyrovanadate species. A one-drop addition of $10 \mathrm{~N} \mathrm{NaOH}$ resulted in a $\mathrm{pH}$ increase to 9.21 with no observable color change. After $24 \mathrm{~h}$ the $\mathrm{pH}$ had drifted down to 6.34. Another drop of $10 \mathrm{~N} \mathrm{NaOH}$ was added and the $\mathrm{pH}$ increased to 8.97 . After $27 \mathrm{~h}$ the $\mathrm{pH}$ had drifted to 6.63 and the color was observed to have changed to yellow. NMR spectra on the $\mathrm{pH} 6.63$ solution showed the presence of decavanadate, metavanadate, and pyrovanadate, but the relative amount of metavanadate and pyrovanadate increased dramatically compared to the initial solution. Addition of a third drop of $10 \mathrm{~N} \mathrm{NaOH}$ caused the $\mathrm{pH}$ to increase to 9.16 with no observable change in color. NMR showed this solution to contain $V_{1}$ and an increase in $V_{1}$ and $V_{2}$ concentration compared to other forms of vanadate. This experiment demonstrated that vanadates tend to form simple tetrahedral units upon alkalization.

Figure 5 shows NMR spectra from $100 \mathrm{mM} \mathrm{NaVO}$ solutions exposed to a pure aluminum wire. This experiment was carried out to understand how contact with a reducing metal might affect speciation of vanadate in solution. Spectra A and B are from a solution initially containing decavanadate. When an aluminum wire was placed into a pH $6.08100 \mathrm{mM} \mathrm{NaVO}_{3}$ orange solution (spectra A), the amount of metavanadate increased relative to decavanadate (spectra B). Within $4 \mathrm{~h}$, the solution color was observed to change from orange to an emerald green, and after $52 \mathrm{~h}$ the solution had turned dark green. Over the course of these color changes the $\mathrm{pH}$ remained near 6 . The green solution may be an indication of the formation of a vanadous ion $\left(\mathrm{V}^{3+}, \mathrm{VOH}^{2+}\right.$, or $\left.\mathrm{VO}^{+}\right)$from the reduction of $\mathrm{V}^{5+} .^{24}$

Spectra C and D in Fig. 5 show behavior in a solution that was initially free of decavanadate. Spectrum $\mathrm{C}$ shows the initial solution dominated by tetrahedrally coordinated metavandates. After $4 \mathrm{~h}$ of contact by an $\mathrm{Al}$ wire, the solution color had changed from a pale yellow to clear, but the NMR signature was largely unchanged. The only difference noted was a small shift in the $\mathrm{V}_{1}$ position, perhaps associated with an increase in $\mathrm{pH}$. The VX species detected is likely a peroxovanadium complex resulting from solution treatment with $\mathrm{H}_{2} \mathrm{O}_{2}$ prior to contact with $\mathrm{Al}^{23}$ The results of this experiment sug- 

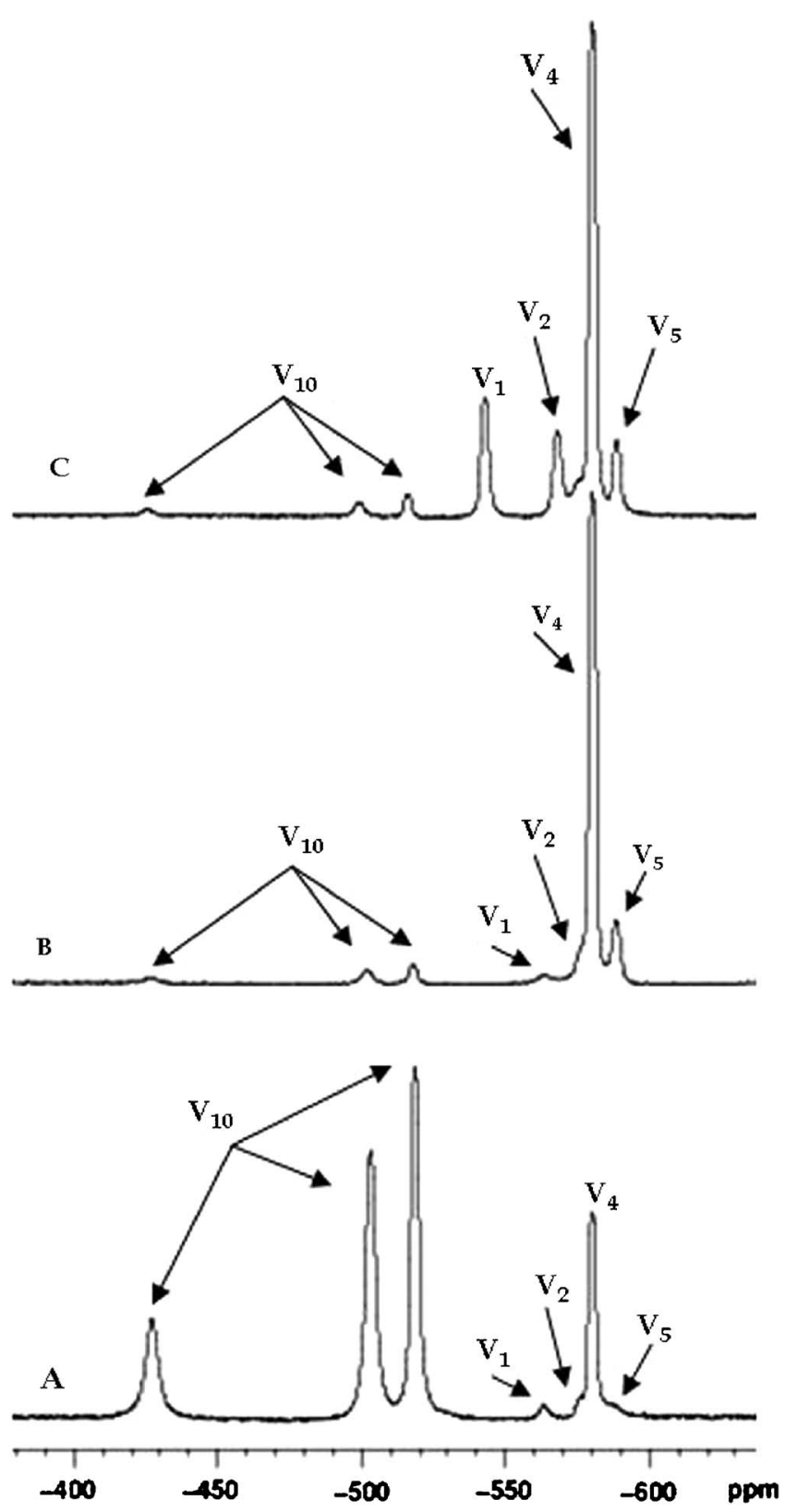

Figure 4. $\mathrm{NaVO}_{3}$ solution after serial additions of $10 \mathrm{~N} \mathrm{NaOH}$ : (A) initial orange $100 \mathrm{mM} \mathrm{NaVO}_{3}$ solution at $\mathrm{pH} 6.08$; (B) yellow $\mathrm{pH} 6.63$ solution $27 \mathrm{~h}$ after the addition of a second drop of $10 \mathrm{~N} \mathrm{NaOH}$ immediately prior to a third $\mathrm{NaOH}$ addition (spectrum collected at $52 \mathrm{~h}$ total); (C) yellow $\mathrm{pH} 9.15$ solution, NMR sample taken and $\mathrm{pH}$ measured approximately 30 min after the addition of a third drop of $10 \mathrm{~N} \mathrm{NaOH}$ (spectrum collected at $52 \mathrm{~h}$ total).

gest that strongly reducing metals like aluminum accelerate decomposition of decavanadates by reduction, while tetrahedral vanadate species remain stable against reduction.

Soluble inhibitor release from pigments. - Synthetic hydrotalcites are anionic exchange clays that consist of alternating positively charged cation layers and negatively charged, exchangeable anion layers. ${ }^{20,25}$ Hydrotalcites may be used as corrosion-inhibiting pigments in organic coatings to deliver inhibiting anions by exchange with anions in the attacking solution. Hydrotalcites synthesized with exchangeable decavanadate have been observed to provide significant corrosion protection to aluminum alloys. ${ }^{8,20}$ However, other work has shown decavanadate to be a poor inhibitor of corrosion on aluminum. ${ }^{3}$ Therefore, the aim of the present experiment was to

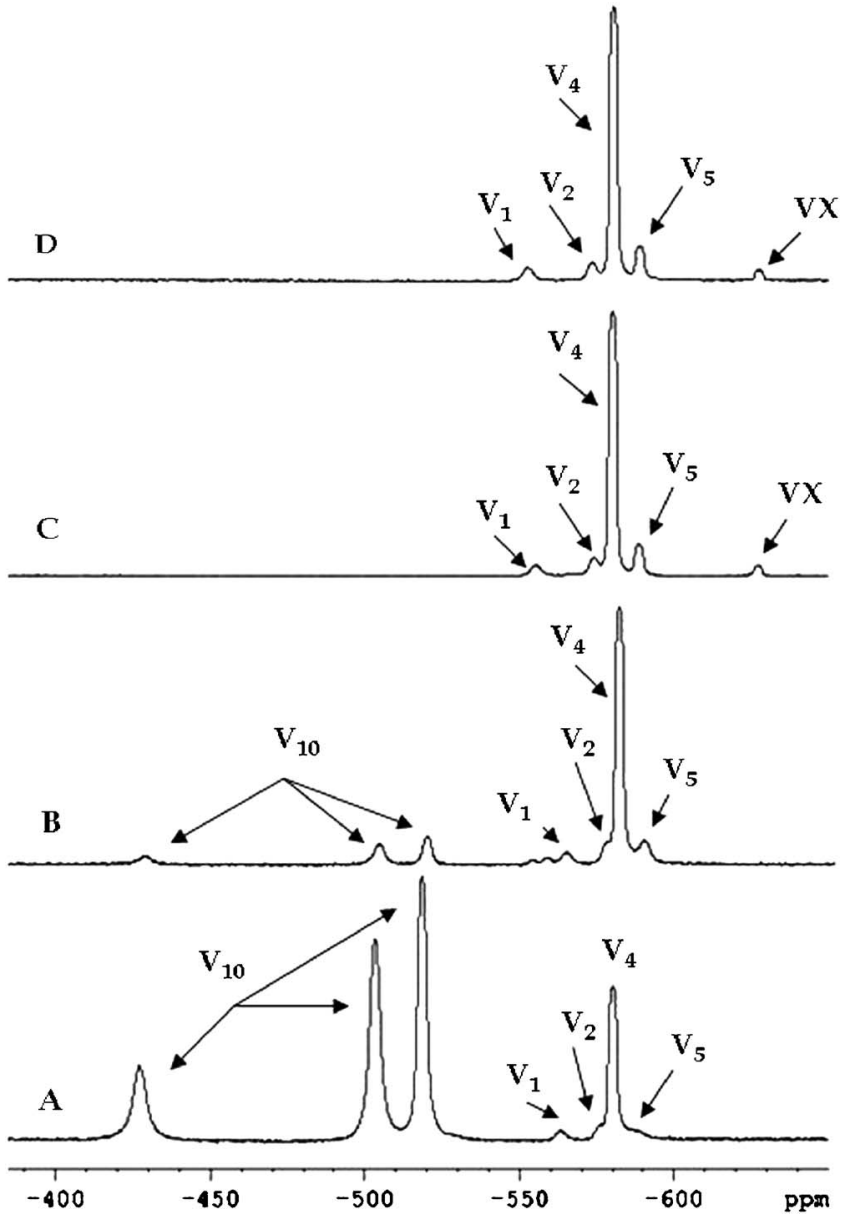

Figure 5. NMR spectra of $100 \mathrm{mM} \mathrm{NaVO}_{3}$ solutions in contact with a pure Al wire: (A) initial orange decavanadate-metavanadate $\mathrm{pH} 6.08$ solution prior to exposure, (B) dark emerald green solution with $\mathrm{pH}$ near 6 after $52 \mathrm{~h}$ of contact, (C) initial pale yellow decavanadate-free $\mathrm{pH} 8.10$ solution prior to contact, and (D) clear decavanadate-free solution after $52 \mathrm{~h}$ of contact.

determine what species are released from a decavanadate-bearing hydrotalcite. Figure 6 is the NMR spectra of filtrate solution from $4.0 \mathrm{~g}$ of a hydrotalcite pigment containing exchangeable decavanadate (HT-V) soaked in $40 \mathrm{~mL}$ of $0.1 \mathrm{M} \mathrm{NaCl}$ at $\mathrm{pH} 6.0$ for $20 \mathrm{~h}$. The

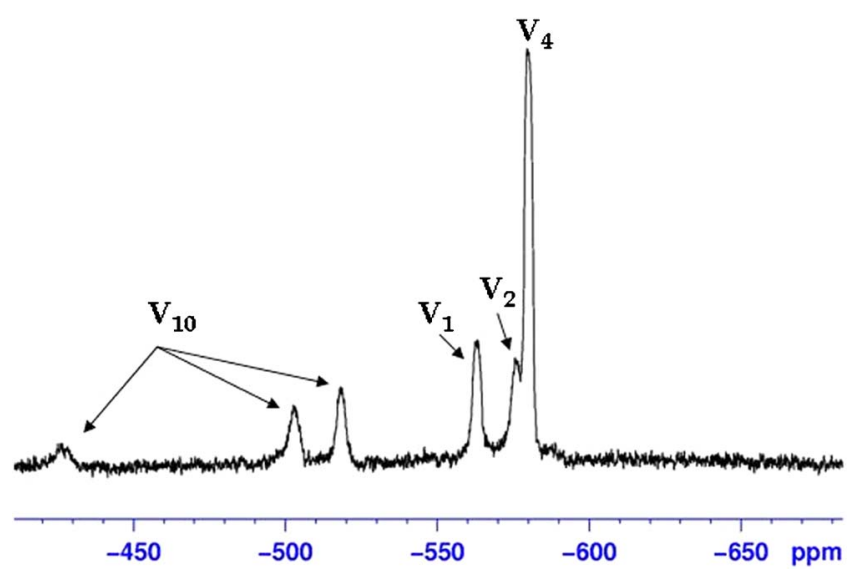

Figure 6. (Color online) NMR spectrum of filtrate from $4.0 \mathrm{~g}$ of an $\mathrm{Al}-\mathrm{Zn}-\mathrm{V}$ hydrotalcite pigment soaked in $40 \mathrm{~mL}$ of $0.1 \mathrm{M} \mathrm{NaCl}$ for $20 \mathrm{~h}$, solution $\mathrm{pH} 6$. 

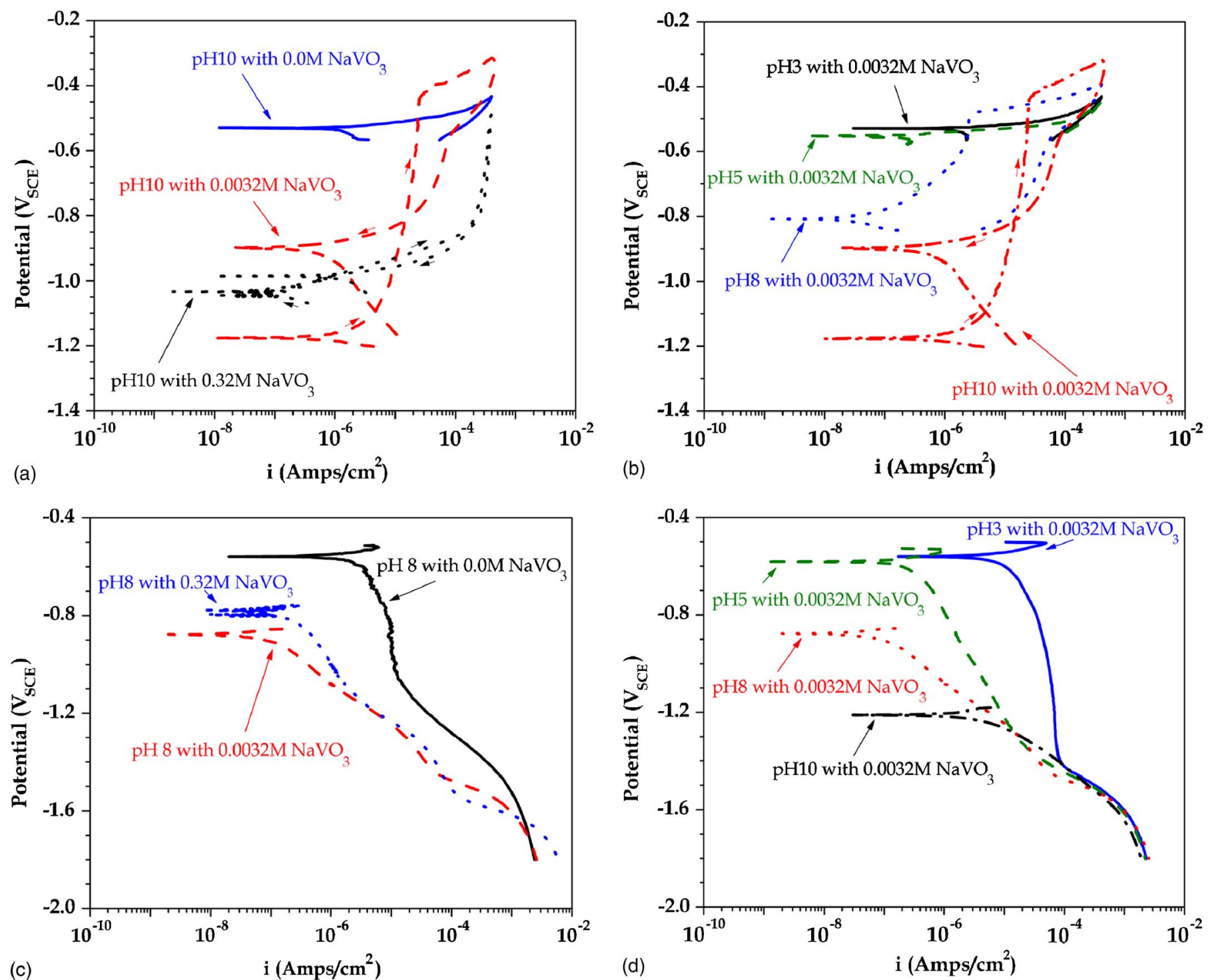

Figure 7. (Color online) Anodic and cathodic polarization curves for $\mathrm{Al} 2024-\mathrm{T} 3$ in $50 \mathrm{mM} \mathrm{NaCl}$ solution with (a) constant $\mathrm{pH} 10$ adjusted solution and varied $\mathrm{NaVO}_{3}$ concentration, (b) constant $0.0032 \mathrm{M} \mathrm{NaVO}_{3}$ solution and varied $\mathrm{pH}$, (c) constant $\mathrm{pH} 8$ solution and varied $\mathrm{NaVO}_{3}$ concentration, and (d) constant $0.0032 \mathrm{M} \mathrm{NaVO}_{3}$ concentration and varied $\mathrm{pH}$.

filtrate solution from a HT-V pigment was observed to contain both octahedrally coordinated decavanadates and tetrahedrally coordinated metavanadate and pyrovanadate species. The relative proportions of the tretrahedrally coordinated forms to octahedrally coordinated forms is greater than might be expected based on the data presented in Fig. 3. The following sections illustrate the correlation between the presence of tetrahedral forms of vanadate in solution and inhibition.

Aluminum 2024-T3 aerated polarization in $\mathrm{NaCl}$ solutions.Figure 7 shows anodic and cathodic polarization curves measured for $\mathrm{Al} 2024-\mathrm{T} 3$ in $50 \mathrm{mM} \mathrm{NaCl}$ solution. In these experiments, the solution $\mathrm{pH}$ and $\mathrm{NaVO}_{3}$ concentration were systematically varied from experiment to experiment. Figure 7 a shows anodic polarization curves at $\mathrm{pH} 10$ for several different $\mathrm{NaVO}_{3}$ concentrations. In basic solutions, the corrosion potential was observed to shift to more active potentials; corrosion current decreased in the presence of vanadate. In the case of the $0.0032 \mathrm{M} \mathrm{NaVO}_{3}$ addition, an increase in pitting potential was observed. Figure $7 \mathrm{~b}$ shows anodic polarization curves with a constant $\mathrm{NaVO}_{3}$ concentration $(0.0032 \mathrm{M})$ with varied $\mathrm{pH}$. Compared to control experiments in chloride-only solutions at $\mathrm{pH} 3,5,8$, and 10 (not shown), the corrosion potential became more active, corrosion current decreased, and the pitting potential increased, but only in alkaline solutions ( $\mathrm{pH} 8$ and 10). Figure $7 \mathrm{c}$ shows cathodic polarization curves collected in $\mathrm{pH} 8$ solutions with varied $\mathrm{NaVO}_{3}$ concentration. Here, addition of $\mathrm{NaVO}_{3}$ resulted in more active corrosion potentials and an overall decrease in cathodic kinetics. Figure $7 \mathrm{~d}$ shows cathodic polarization curves with constant $0.0032 \mathrm{M} \mathrm{NaVO}_{3}$ concentration with varied $\mathrm{pH}$. As solution $\mathrm{pH}$ increased, reduction kinetics were observed to slow compared to those measured in chloride-only solutions at $\mathrm{pH} 3,5,8$, and 10 (not shown). The observation that anodic and cathodic inhibitions were more evident in alkaline solutions than in acidic ones is consistent with the idea that inhibition is associated with the presence of tetrahedrally coordinated metavanadate and pyrovanadate species.

The effects of $\mathrm{pH}$ and vanadate concentration on the potentiodynamic polarization response and corrosion inhibition are summarized in Fig. 8. Corrosion potential and current were obtained from polarization curves by extrapolation carried out with the aid of Corrview software. Figure 8a shows changes in corrosion potential as a function of $\mathrm{pH}$ and $\mathrm{NaVO}_{3}$ concentration. Each data point represents 

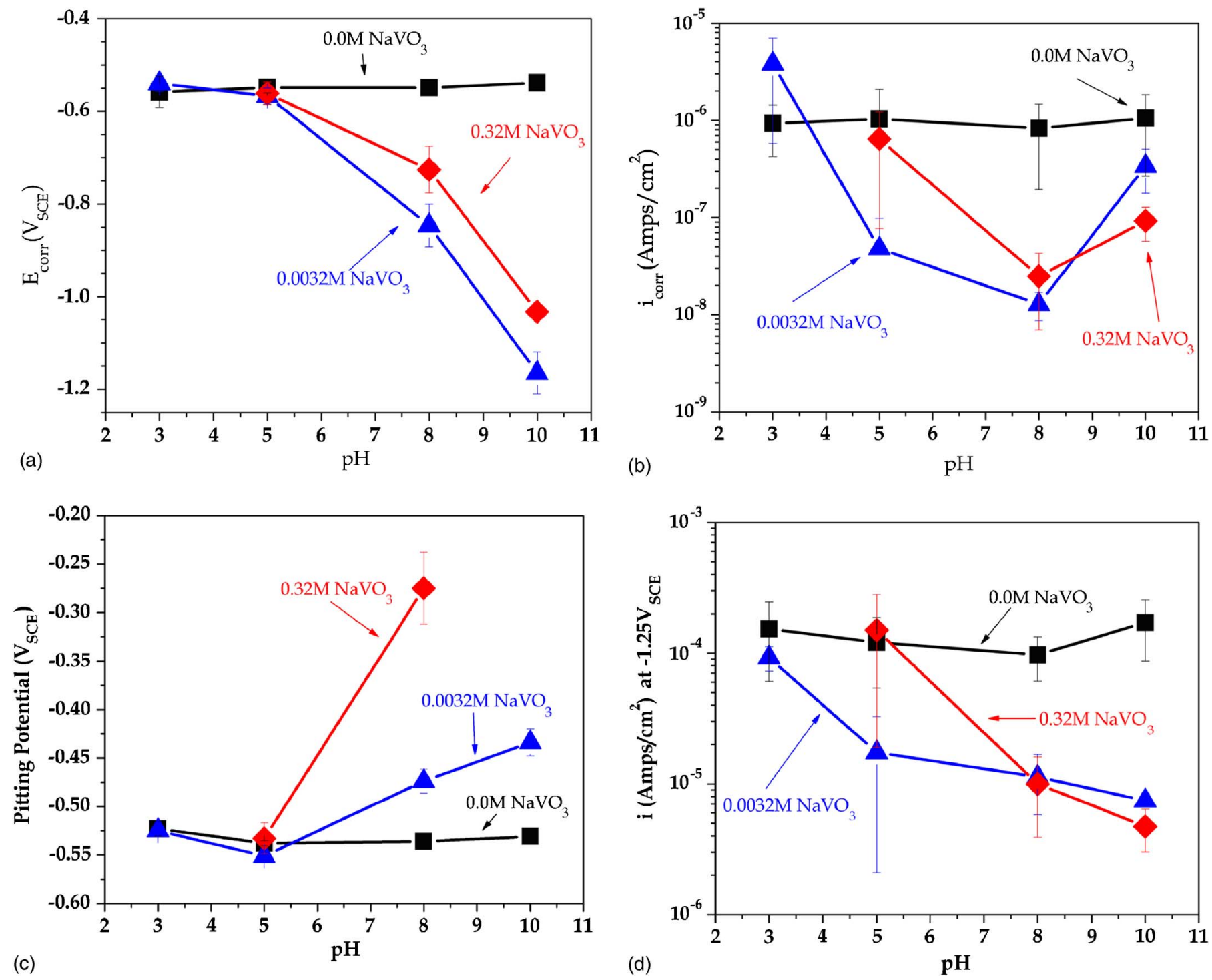

Figure 8. (Color online) Condensed data from aerated polarization experiments: (a) corrosion potential as a function of pH, (b) corrosion current as a function of $\mathrm{pH}$, (c) pitting potential as a function of $\mathrm{pH}$, and (d) cathodic current at $-1.25 \mathrm{~V}_{\mathrm{SCE}}$ as a function of $\mathrm{pH}$.

the average of eight experiments. The figure shows that $\mathrm{NaVO}_{3}$ additions have no effect at $\mathrm{pH} 3$ and 5 , but lead to a considerable decrease in corrosion potential at $\mathrm{pH} 8$ and 10 . Figure $8 \mathrm{~b}$ shows changes in corrosion current density as a function of $\mathrm{pH}$ with $\mathrm{NaVO}_{3}$ addition. Approximately an order of magnitude reduction in corrosion current was observed at $\mathrm{pH} 8$ and 10 in solutions with $\mathrm{NaVO}_{3}$. At pH 5, high concentrations of $\mathrm{NaVO}_{3}$ resulted in a modest reduction of corrosion current with greater inhibition occurring at lower vanadate concentrations. Figure $8 \mathrm{c}$ shows changes in pitting potential. In the $0.32 \mathrm{M} \mathrm{NaVO}_{3}$ solutions, breakdown was not observed at the point of scan reversal and was not included in the plot. Generally, the pitting potential was observed to increase in alkaline solutions containing $\mathrm{NaVO}_{3}$. Figure 8d shows a comparison of the cathodic current density at $-1.25 \mathrm{~V}_{\mathrm{SCE}}$ of $\mathrm{NaVO}_{3}$ solutions as a function of $\mathrm{pH}$. The current density at $-1.25 \mathrm{~V}_{\mathrm{SCE}}$ was used as a point of comparison between different experiments, because this is a point below the lowest corrosion potential observed and allows direct comparison of reduction kinetics from all the collected data. The data shows an order of magnitude or greater decrease in current density at $-1.25 \mathrm{~V}_{\mathrm{SCE}}$ for alkaline solutions containing $\mathrm{NaVO}_{3}$ compared to those without. At around $\mathrm{pH} 5$, the more dilute vanadate solutions slow cathodic kinetics more than concentrated ones.
Aluminum 2024-T3 deaerated polarization in NaCl solution.Figure 9 shows variations in the polarization characteristics as a function of $\mathrm{pH}$ and $\mathrm{NaVO}_{3}$ concentration in deaerated $50 \mathrm{mM} \mathrm{NaCl}$ solutions. All experiments were run in duplicate at a minimum. Figure 9 a shows corrosion potential as a function of $\mathrm{pH}$ in deaerated solutions with and without $\mathrm{NaVO}_{3} \cdot \mathrm{NaVO}_{3}$ ennobles the corrosion potential in acidic deaerated solutions but has little effect in alkaline solutions. Figure $9 \mathrm{~b}$ shows the variation in corrosion current density. $\mathrm{NaVO}_{3}$ in acidic deaerated solutions was observed to increase corrosion current; a decrease in corrosion current was observed in alkaline solutions, particularly at $\mathrm{pH} 10$. Figure $9 \mathrm{c}$ shows the variation in pitting potential. The data is similar to the data collected in aerated solutions showing an increase in pitting potential in alkaline $\mathrm{NaVO}_{3}$ solutions. Suppression of pitting by vanadates in alkaline solutions appears to be relatively independent of the extent of solution aeration. Figure $9 \mathrm{~d}$ shows current density at $-1.25 \mathrm{~V}_{\mathrm{SCE}}$. There is no significant reduction in the cathodic kinetics associated with the presence of $\mathrm{NaVO}_{3}$ except at $\mathrm{pH} 10$. This suggests that cathodic inhibition by vanadate is largely through the suppression of oxygen reduction with little effect on hydrogen evolution. 

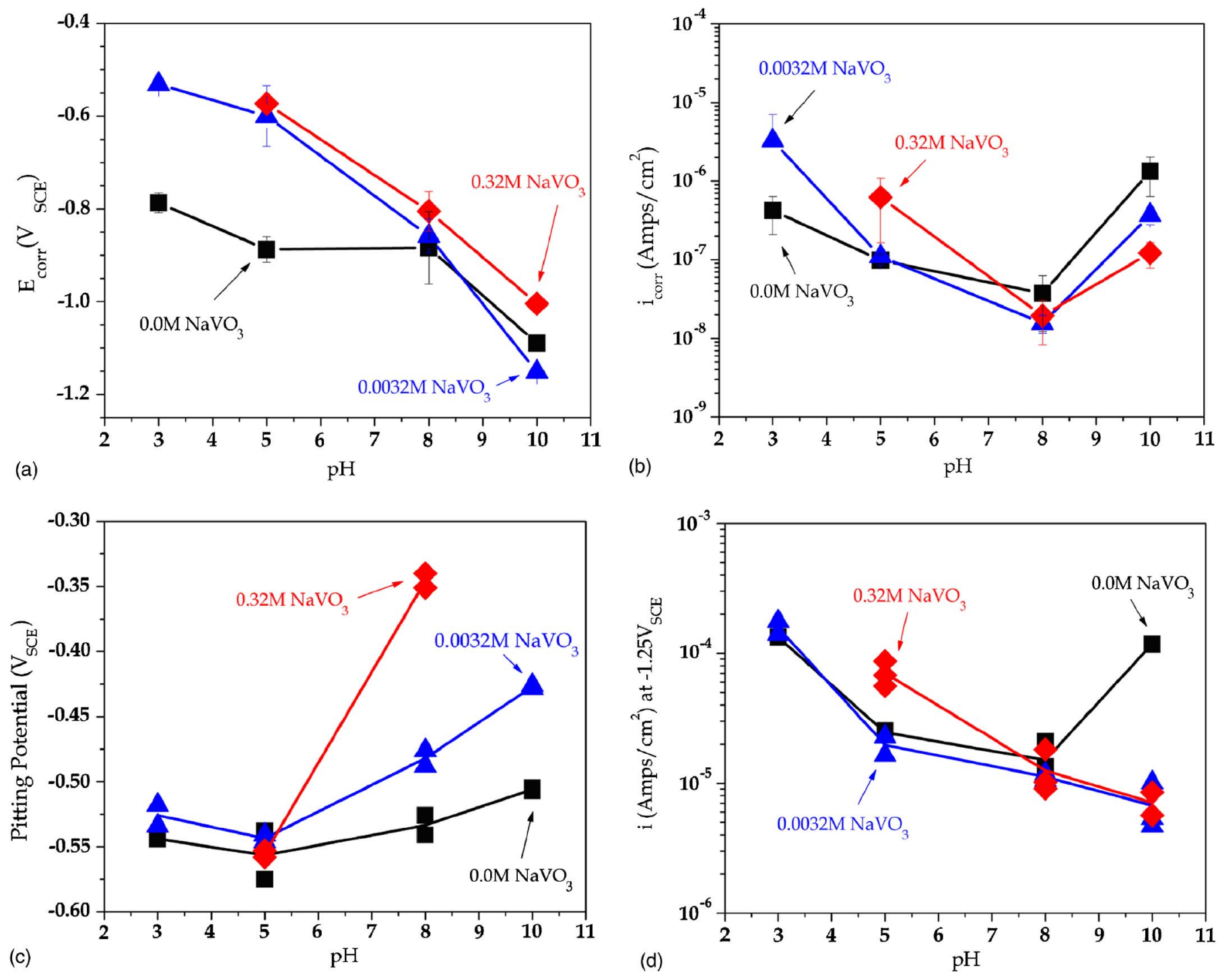

Figure 9. (Color online) Condensed data from deaerated polarization experiments: (a) corrosion potential as a function of pH, (b) corrosion current as a function of $\mathrm{pH}$, (c) pitting potential as a function of $\mathrm{pH}$, and (d) cathodic current at $-1.25 \mathrm{~V}_{\mathrm{SCE}}$ as a function of $\mathrm{pH}$.

Corrosion morphology of aluminum in vanadate solution.Figure 10 shows images and chemical maps collected in the vicinity of constituent particle clusters in polished Al 2024-T3 surfaces after immersion in aerated $\mathrm{pH} 10,50 \mathrm{mM} \mathrm{NaCl}$, with and without $\mathrm{NaVO}_{3}$. A description of constituent particles in aluminum alloys and $\mathrm{Al}_{2} \mathrm{CuMg}$ dissolution can be found in the literature. ${ }^{17,26,27}$ There was no evidence of $\mathrm{Mg}$ at particle locations in chemical maps on samples exposed in $\mathrm{NaVO}_{3}$-free solutions at any $\mathrm{pH}$ tested $(3,5,8$, and 10). This indicates selective dissolution of $\mathrm{Mg}$ from $\mathrm{Al}_{2} \mathrm{CuMg}$ particles. In contrast, in alkaline solutions containing $\mathrm{NaVO}_{3}$, chemical maps showed both $\mathrm{Mg}$ and $\mathrm{Cu}$ present at particle locations. Even in mildly acidic solutions with $\mathrm{NaVO}_{3}$, small amounts of $\mathrm{Mg}$ were detected. These findings indicate that vanadate additions suppress dealloying of $\mathrm{Cu}$ and $\mathrm{Mg}$-bearing particles.

Figure 11 is a collection of chemical maps obtained from $\mathrm{Al}$ 2024-T3 exposed to aerated $50 \mathrm{mM} \mathrm{NaCl}$ showing different manifestations of vanadium deposition on the surface of Al 2024-T3 at different $\mathrm{pH}$ and $\mathrm{NaVO}_{3}$ concentrations. Typically, in acidic solutions, where polarization results indicated no significant inhibition, high concentrations of vanadium were observed in areas of localized corrosion, such as near pits and filiform tracks. There is some evidence that the vanadium is only present near pits which contain copper. Vanadium was not observed near $\mathrm{Fe}-\mathrm{Mn}$ or $\mathrm{Fe}-\mathrm{Mn}-\mathrm{Cu}$ intermetallic particles. Despite the fact that mildly alkaline solutions provided the strongest inhibition according to polarization results, no vanadium was detected near areas of attack or on specific intermetallic particles. In strongly alkaline solutions and those with high concentrations of $\mathrm{NaVO}_{3}$, in which polarization scans also indicated corrosion inhibition, no significant vanadium segregation was observed in areas of attack; however, patches or a dusting of vanadium was observed over large portions of the surface. Further, an association between $\mathrm{Al}_{2} \mathrm{CuMg}$ particles and vanadium was sometimes observed in strongly alkaline solutions with $\mathrm{NaVO}_{3}$. In summary, the solutions that demonstrated the strongest inhibition typically resulted in postexposure surfaces characterized by intact $\mathrm{Al}_{2} \mathrm{CuMg}$ particles, possibly the result of vanadium deposition at levels below EDS detection limits.

\section{Discussion}

Speciation vs corrosion inhibition.- The formation of decavanadate results in a distinct orange-colored solution. The formation of metavanadate and pyrovanadate from an orange decavanadate solution is not immediately accompanied by a visually detectable 

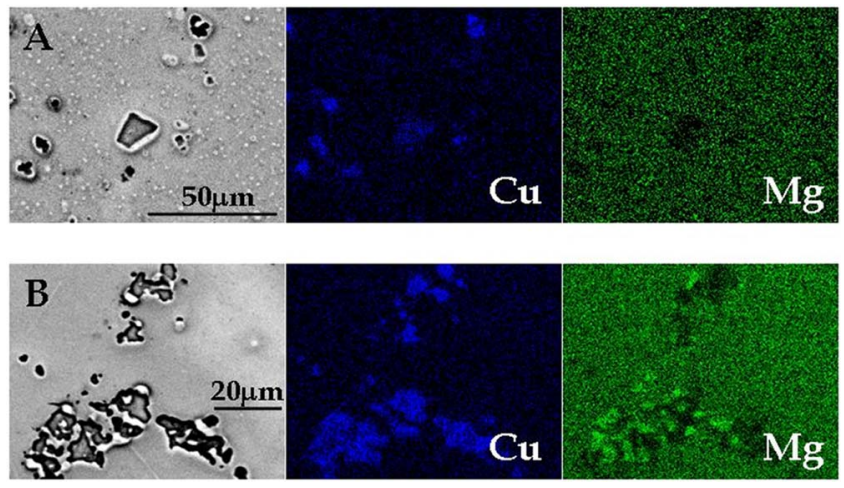

Figure 10. (Color online) Sample chemical maps collected in aerated $50 \mathrm{mM} \mathrm{NaCl}$ showing observed suppression of S-phase dissolution in alkaline $\mathrm{NaVO}_{3}$ solutions compared to vanadate-free solutions: (A) $\mathrm{pH} 10,0.0 \mathrm{M}$ $\mathrm{NaVO}_{3}$; (B) pH 10, $0.0032 \mathrm{M} \mathrm{NaVO}_{3}$.

color change. Given enough time and alkali dose, the solution will turn yellow or clear with an appropriate $\mathrm{NaVO}_{3}$ concentration, and tetrahedral vanadates will dominate the vanadate solution chemistry.

In these experiments, the best overall inhibition was observed in alkaline $0.0032 \mathrm{M} \mathrm{NaVO}_{3}$ solutions. However, good inhibition was observed in alkaline solutions with $0.32 \mathrm{M} \mathrm{NaVO}_{3}$, and even reasonable inhibition was seen in $0.0032 \mathrm{M} \mathrm{NaVO}_{3}$ solutions at $\mathrm{pH} 5$. The equilibrium predominance diagram in Fig. 1 gives a general idea of the types of species present in a solution of given $\mathrm{pH}$ and concentration, however, a number of other species are also likely to be present. Interpretation of experimental results and conclusions about speciation and resultant inhibition must be made with that fact
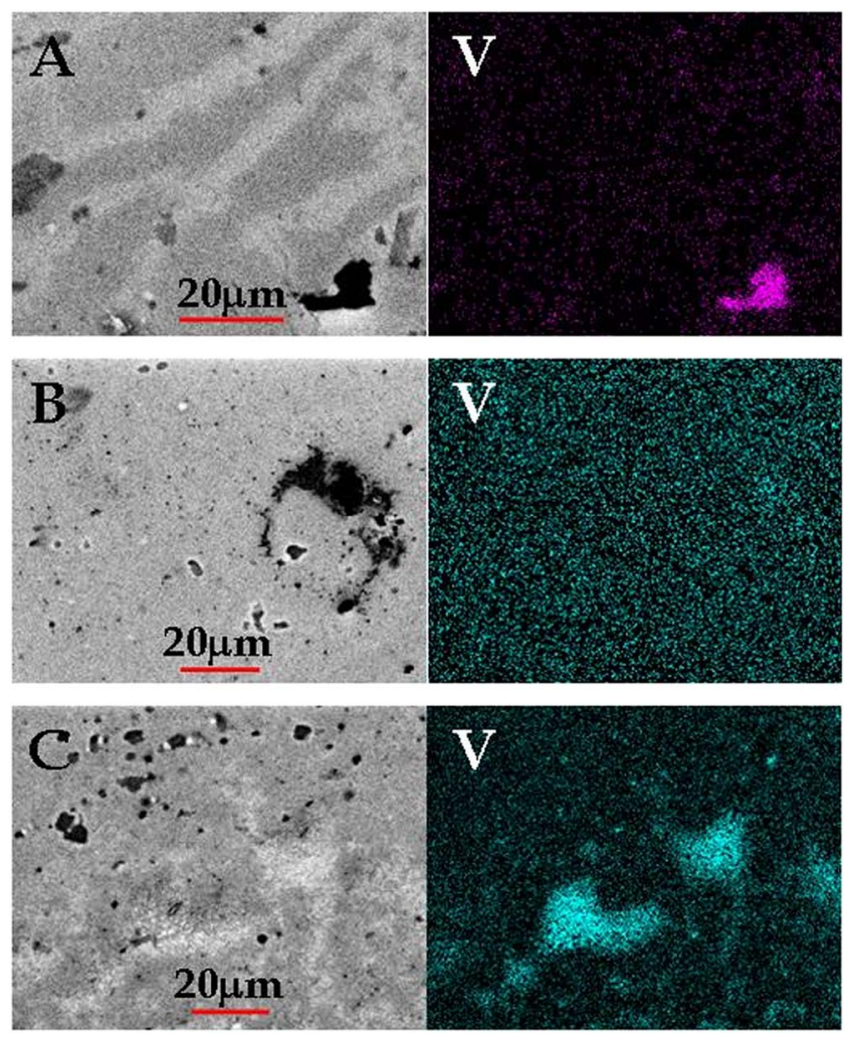

Figure 11. (Color online) Sample chemical maps collected in aerated $50 \mathrm{mM} \mathrm{NaCl}$ showing different manifestations of vanadium on the surface of Al 2024-T3: (A) pH 5, $0.32 \mathrm{M} \mathrm{NaVO}_{3}$; (B) $\mathrm{pH} 8,0.0032 \mathrm{M} \mathrm{NaVO}_{3}$; and (C) $\mathrm{pH}, 0.32 \mathrm{M} \mathrm{NaVO}_{3}$.
Table I. List of probable vanadium species in solutions of varied $\mathrm{NaVO}_{3}$ concentration and $\mathrm{pH}$. The vertical lines delineate vanadate solutions that demonstrated inhibition, on the right, from solutions in which inhibition was not observed, on the left. Species listed in bold are likely present in relatively small concentrations compared to the nonbold species.

\begin{tabular}{|c|c|c|c|c|}
\hline & pH 3 & pH 5 & pH 8 & $\mathrm{pH} 10$ \\
\hline $\begin{array}{l}0.32 \mathrm{M} \\
\mathrm{NaVO}_{3}\end{array}$ & $\begin{array}{l}\mathrm{V}_{10} \mathrm{O}_{26}(\mathrm{OH})_{2}^{4-} \\
\mathrm{V}_{10} \mathrm{O}_{27}(\mathrm{OH})_{2}^{5-}\end{array}$ & $\begin{array}{c}\mathrm{V}_{10} \mathrm{O}_{27}(\mathrm{OH})^{5-} \\
\mathrm{V}_{10} \mathrm{O}_{28} \\
\mathbf{V}_{\mathbf{1 0}} \mathbf{O}_{\mathbf{2 6}}(\mathbf{O H})_{2}^{\mathbf{4}}\end{array}$ & $\begin{array}{c}\mathrm{V}_{4} \mathrm{O}_{12}^{4-} \\
\mathrm{V}_{3} \mathrm{O}_{9}^{3-} \\
\mathbf{V O}_{\mathbf{3}}(\mathbf{O H})^{\mathbf{2 -}} \\
\mathbf{V}_{\mathbf{2}} \mathbf{O}_{\mathbf{6}}(\mathbf{O H})^{\mathbf{3 -}}\end{array}$ & $\begin{array}{c}\mathrm{V}_{2} \mathrm{O}_{7}^{4-} \\
\mathrm{VO}_{3}(\mathrm{OH})^{2-} \\
\mathrm{V}_{2} \mathrm{O}_{6}(\mathrm{OH})^{3-}\end{array}$ \\
\hline $\begin{array}{l}0.0032 \mathrm{M} \\
\mathrm{NaVO}_{3}\end{array}$ & $\begin{array}{c}\mathrm{V}_{10} \mathrm{O}_{26}(\mathrm{OH})_{2}^{4-} \\
\mathrm{V}_{10} \mathrm{O}_{27}(\mathrm{OH})^{5-} \\
\mathrm{VO}_{2}^{+} \\
\mathrm{VO}(\mathrm{OH})_{3} \\
\mathbf{V O}_{2}(\mathrm{OH})_{2}^{-}\end{array}$ & $\begin{array}{c}\mathrm{V}_{10} \mathrm{O}_{27}(\mathrm{OH})^{5-} \\
\mathrm{V}_{3} \mathrm{O}_{9}^{3-} \\
\mathrm{VO}_{2}(\mathrm{OH})_{2}^{-} \\
\mathrm{V}_{10} \mathrm{O}_{28}^{6-} \\
\mathbf{V}_{\mathbf{4}} \mathbf{O}_{12}^{4-} \\
\mathbf{V}_{10} \mathbf{O}_{\mathbf{2 6}}(\mathbf{O H})_{2}^{4-}\end{array}$ & $\begin{array}{c}\mathrm{V}_{3} \mathrm{O}_{9}^{3-} \\
\mathrm{VO}_{3}(\mathrm{OH})^{2-} \\
\mathrm{VO}_{2}(\mathrm{OH})_{2}^{-} \\
\mathrm{V}_{4} \mathrm{O}_{12}^{4-} \\
\mathrm{V}_{2} \mathrm{O}_{6}(\mathrm{OH})^{3-}\end{array}$ & $\begin{array}{c}\mathrm{VO}_{3}(\mathrm{OH})^{2-} \\
\mathrm{V}_{2} \mathrm{O}_{7}^{4-}\end{array}$ \\
\hline
\end{tabular}

in mind. Table I is a summary of possible species that might be found at different combinations of $\mathrm{pH}$ and concentrations at which experiments were performed; species are listed in order of abundance. ${ }^{13}$ A comparison of Table I with experimental results shows that inhibition is strongly correlated with the presence of tetrahedrally coordinated species in solution. This includes the metavanadates and pyrovanadates, with the strongest inhibition possibly correlated to single vanadate tetrahedra, as previously suggested. ${ }^{3}$

Polarization data collected from 2024-T3 exposed to a $0.32 \mathrm{M}$ $\mathrm{NaVO}_{3}$ solution at $\mathrm{pH} 5$ and a $0.0032 \mathrm{M} \mathrm{NaVO}_{3}$ at $\mathrm{pH} 3$ show no evidence of inhibition. Octahedrally coordinated decavanadates prevail under these conditions and do not appear to directly contribute inhibition. In fact, the ennobled corrosion potentials and increased corrosion current densities in deaerated acidic conditions (Fig. 9a and b) suggest that decavanadates are oxidizing agents. ${ }^{5,13}$ Reduced forms of vanadium noted in the presence of pure Al may arise from reduction of decavanadates.

At $\mathrm{pH} 5$ and 8, the polarization response characteristics suggest that $0.0032 \mathrm{M} \mathrm{NaVO}_{3}$ additions are more inhibiting than $0.32 \mathrm{M}$ additions (Fig. 8). This is consistent with inhibition dominated by tetrahedrally coordinated forms of vanadate. Figure 1 shows that at $\mathrm{pH} 5$, tetrahedral vanadates predominate at lower concentrations and octahedral forms predominate at higher concentrations. The differences in the extent of inhibition in $\mathrm{pH} 5$ solutions at the two concentration ranges used in this study clearly show that there can be an inverse relationship between vanadate concentration and effectiveness of inhibition in mildly acidic, neutral, and perhaps mildly alkaline solutions. It is also of interest that vanadates operate as cathodic inhibitors over the widest $\mathrm{pH}$ range when present in dilute concentrations.

Under strong alkaline conditions where vanadate is speciated almost exclusively in tetrahedrally coordinated forms, vanadate inhibition exhibits a more regular dependence on $\mathrm{NaVO}_{3}$ concentration. Anodic and cathodic inhibition are demonstrated. Under these conditions, a combination of the following species is expected: $\mathrm{V}_{4} \mathrm{O}_{12}^{4-}$, $\mathrm{V}_{3} \mathrm{O}_{9}^{3-}, \mathrm{VO}_{3}(\mathrm{OH})^{2-}, \mathrm{V}_{2} \mathrm{O}_{7}^{4-}, \mathrm{V}_{2} \mathrm{O}_{6}(\mathrm{OH})^{3-}$, and $\mathrm{VO}_{2}(\mathrm{OH})_{2}^{-}$. Among these, the strongest inhibition was observed in the presence of tetrahedral pyrovanadate $\mathrm{VO}_{3}(\mathrm{OH})^{2-}$. 3 However, this does not exclude other metavanadate and pyrovanadate species from providing inhibition, either directly or indirectly, through respeciation into $\mathrm{V}_{1}$. For instance, strong inhibition was observed in $\mathrm{pH} 80.32 \mathrm{M} \mathrm{NaVO}$ solutions which likely contain relatively small concentrations of $\mathrm{VO}_{3}(\mathrm{OH})^{2-}$ relative to $\mathrm{V}_{4} \mathrm{O}_{12}^{4-}$ and $\mathrm{V}_{3} \mathrm{O}_{9}^{3-}$. It is not clear whether sufficient concentrations of $\mathrm{VO}_{3}(\mathrm{OH})^{2-}$ initially exist in solution to account for observed inhibition or if $\mathrm{V}_{4} \mathrm{O}_{12}^{4-}$ and $\mathrm{V}_{3} \mathrm{O}_{9}^{3-}$ directly inhibit or rapidly speciate into inhibiting species. 
Inhibition and oxygen dependence.- Vanadates inhibit both anodic and cathodic reactions. Anodic inhibition, as assessed by the effect on the pitting potential, seems to be independent of oxygen. In this regard, vanadates are similar to chromates in that both may act as anodic inhibitors, regardless of solution oxygen content. ${ }^{28}$ This is an advantage over other anodic inhibitors, such as phosphates, molybdates, and silicates, which function best in oxygenated environments. ${ }^{28}$

Tetrahedrally coordinated vanadates are inhibitors of oxygen reduction on $\mathrm{Al}$ 2024-T3. The trends in oxygen reduction closely mirror those that favor speciation of vanadates in their tetrahedral form. Inhibition of oxygen reduction shifts the corrosion potential in the negative direction. Because tetrahedral vanadates simultaneously increase the pitting potential, the tendency for localized corrosion under free corrosion conditions is significantly decreased.

Apparent acceleration of cathodic kinetics in both aerated and deaerated environment occurs under conditions where octahedrally coordinated vanadates are expected to be present. In these cases, increased cathodic kinetics is associated with reduction of decavanadates.

Action of vanadates on Al alloy surfaces. - Copper-containing intermetallic particles have been reported to play a central role in localized corrosion of Al 2024-T3, essentially acting as local cathodes leading to localized cathodic corrosion. ${ }^{29}$ In particular, $\mathrm{Al}-\mathrm{Cu}-\mathrm{Mg}$ intermetallic particles have been reported to account for a large percentage of all particles in number and area fraction. ${ }^{26}$ $\mathrm{Al}_{2} \mathrm{CuMg}$, S-phase, under free corrosion conditions, is initially active to the surrounding matrix due to constituent magnesium. ${ }^{27}$ Strong anodic polarization of the intermetallic causes dealloying and magnesium dissolution, and the remaining copper will function as a strong local cathode which supports oxygen reduction. ${ }^{27}$ In light of observed anodic and cathodic inhibition in alkaline solutions, it is interesting that chemical maps show that $\mathrm{Al}-\mathrm{Cu}-\mathrm{Mg}$ intermetallic particles remain relatively intact after exposure experiments to $\mathrm{pH} 8$ and $10 \mathrm{NaVO}_{3}$ solutions. In contrast, chemical maps in strongly acidic solutions and those with no $\mathrm{NaVO}_{3}$ showed no evidence of magnesium. It is possible that vanadates in alkaline solutions play a role in preventing the rapid dissolution of magnesium from $\mathrm{Al}-\mathrm{Cu}-\mathrm{Mg}$ particles. As a result, these particles may not become strong cathodes that contribute to localized corrosion damage accumulation. A similar observation was made by Iannuzzi et al., where metavanadate solutions were observed to suppress S-phase dissolution. ${ }^{4,30}$

The chemical maps collected in $\mathrm{pH} 8 \mathrm{NaVO}_{3}$ solutions are possible evidence of localized film formation over the matrix (Fig. 11). There is no detectable segregation of vanadium to any intermetallic particles, although the particles appear to be intact. Chemical mapping lacks the sensitivity to detect very thin layers and deposits, and a complete interpretation of vanadate interaction with corroding surfaces is needed to fully describe these interactions.

Vanadate speciation, and vanadates in hydrotalcite pigments.NMR solution experiments show that vanadate solutions are very dynamic, with changes in $\mathrm{pH}$ resulting in rapid changes in speciation. This is true even of the dissociation of decavanadates to metavanadates. Solutions which are dominated by tetrahedrally coordinated vanadates will speciate into octahedrally coordinated vanadates and reach equilibrium quickly after an acidic $\mathrm{pH}$ adjustment. Octahedral vanadate solutions will begin to speciate into tetrahedral vanadates quickly upon alkaline $\mathrm{pH}$ adjustment, but will not reach equilibrium for long periods of time.

This latter point is significant in understanding the behavior of corrosion-inhibiting hydrotalcite pigments. Previous work has shown hydrotalcites containing vanadates inhibit corrosion of $\mathrm{Al}$ 2024-T3 when dispersed into an organic resin and applied as a coating. ${ }^{8,20}$ However, inhibiting forms of vanadate hydrotalcite have only been observed when synthesis is carried out using octahedrally coordinated decavanadates. Speciation of decavanadate to tetrahedrally coordinated forms is essential for corrosion inhibition to be imparted. The presence of tetrahedrally coordinated forms of vanadate in solutions in contact with hydrotalcite pigments shows that inhibiting forms of vanadate develop from this pigment. In coatings on metallic substrates, the generation of tetrahedral forms of vanadate is expected to be further stimulated by local increases in $\mathrm{pH}$ associated with sites supporting oxygen reduction, and the low vanadate concentrations in solution.

\section{Conclusions}

1. Inhibition of $\mathrm{Al} 2024-\mathrm{T} 3$ in $\mathrm{NaCl}$ solutions by vanadates is associated with tetrahedrally coordinated forms of vanadate. Octahedrally coordinated vanadates do not appear to provide inhibition and may accelerate corrosion under deaerated conditions.

2. Upon acidic $\mathrm{pH}$ adjustment of alkaline solutions, speciation and equilibration of octahedral forms of vanadate from tetrahedral forms is fast. Upon alkaline $\mathrm{pH}$ adjustment of acid solutions, speciation of tetrahedral forms of vanadate from octahedral forms begins within minutes of $\mathrm{pH}$ adjustment; however, equilibration is slow.

3. $\mathrm{NaVO}_{3}$ solutions inhibit cathodic kinetics of $\mathrm{Al}$ 2024-T3 corrosion in alkaline aerated $\mathrm{NaCl}$ solutions. $\mathrm{NaVO}_{3}$ solutions were not observed to inhibit cathodic kinetics in deaerated solutions. The main inhibiting action of vanadates on cathodic reactions is suppression of oxygen reduction.

4. An increase in pitting potential was observed in both aerated and deaerated $\mathrm{NaCl}$ solutions where tetrahedrally coordinated vanadates were present. Anodic inhibition from tetrahedrally coordinated vanadates in alkaline solutions is independent of solution aeration.

5. Chemical maps showed intermetallic particles containing magnesium to be largely intact after exposure to $\mathrm{NaCl}$ solution containing tetrahedrally coordinated vanadates.

6. A filtrate solution produced by contact with a decavanadatebearing hydrotalcite inhibitor pigment was shown to contain both metavanadate and decavanadate species. Vanadates in solution will speciate quickly in response to the prevailing $\mathrm{pH}$.

7. Vanadate solution color change is not always a reliable indicator of species present in vanadate solutions.

\section{Acknowledgments}

This work was supported by an Air Force Office of Scientific Research Multi-University Research Initiative under contract no. F49620-01-0352, Major Jennifer Gresham, Program Manager, and by Concurrent Technologies, Inc., Larry Gintert, Program Manager.

Ohio State University assisted in meeting the publication costs of this article.

\section{References}

1. B. R. W. Hinton, Met. Finish., 89, 15 (1991)

2. B. R. W. Hinton, Met. Finish., 89, 55 (1991).

3. M. Iannuzzi, T. Young, and G. S. Frankel, J. Electrochem. Soc., 153, B533 (2006)

4. M. Iannuzzi, J. Kovac, and G. S. Frankel, Electrochim. Acta, 52, 4032 (2007).

5. M. Iannuzzi and G. S. Frankel, Corros. Sci., 49, 2371 (2007).

6. J. R. L. Cook and S. R. Taylor, Corrosion (Houston), 56, 321 (2000).

7. H. Guan and R. G. Buchheit, Corrosion (Houston), 60, 284 (2004).

8. R. G. Buchheit, H. Guan, S. Mahajanam, and F. Wong, Prog. Org. Coat., 47, 174 (2003).

9. J. Livage, Solid State Ionics, 86-88, 935 (1996).

10. J. Livage, Chem. Mater., 3, 578 (1991).

11. T. Prosek and D. Thierry, Corrosion (Houston), 60, 1122 (2004).

12. A. Nazarov, D. Thierry, T. Prosek, and N. L. Bozec, J. Electrochem. Soc., 152, B220 (2005).

13. C. F. Baes, Jr., and R. E. Mesmer, The Hydrolysis of Cations, Robert E. Krieger Publishing Company, Inc., Malabar, FL (1986).

14. M. T. Pope, Heteropoly and Isopoly Oxometalates, p. 34, Springer-Verlag, Berlin (1983)

15. R. J. H. Clark, The Chemistry of Titanium and Vanadium, Elsevier Publishing Co., Amsterdam, The Netherlands (1968).

16. S. S. Soares, H. Martins, R. O. Duarte, J. J. G. Moura, J. Coucelo, C. GutierrezMerino, and M. Aureliano, J. Inorg. Biochem., 101, 80 (2007).

17. I. J. Polmear, Light Alloys Metallurgy of the Light Metals, Arnold, London (1995)

18. H. N. McMurray and G. Williams, Corrosion (Houston), 60, 219 (2004).

19. G. Williams and H. N. McMurray, Electrochem. Solid-State Lett., 6, B9 (2003).

20. S. P. V. Mahajanam, M.S. Thesis, The Ohio State University, Columbus, OH (2005). 
21. A. S. Tracey, J. S. Jaswal, and S. J. Angus-Dunne, Inorg. Chem., 34, 5680 (1995).

22. M. Aureliano and R. M. C. Gandara, J. Inorg. Biochem., 99, 979 (2005).

23. I. Andersson, S. Angus-Dunne, O. Howarth, and L. Pettersson, J. Inorg. Biochem., 80, $51(2000)$.

24. M. Pourbaix, Atlas of Electrochemical Equilibria in Aqueous Solutions, National Association of Corrosion Engineers, Houston, TX (1974).

25. F. Cavani, F. Trifiro, and A. Vaccari, Catal. Today, 11, 173 (1991).

26. R. G. Buchheit, R. P. Grant, P. F. Hlava, B. McKenzie, and G. L. Zender, J.
Electrochem. Soc., 144, 2621 (1997).

27. R. G. Buchheit, L. P. Montes, M. A. Martinez, J. Michael, and P. F. Hlava, J. Electrochem. Soc., 146, 4424 (1999).

28. J. Sinko, Prog. Org. Coat., 42, 267 (2001).

29. T. J. R. Leclere, A. J. Davenport, and R. C. Newman, Corrosion (Houston), 63, 338 (2007).

30. M. Iannuzzi and G. S. Frankel, Corrosion (Houston), 63, 672 (2007). 